DOI https://doi.org/10.36059/978-966-397-144-5/22-43

\title{
THE GLOBALIZATION AND FREEDOM OF PERSONALITY: THE SOCIO-PHILOSOPHICAL ASPECT
}

\section{Atamaniuk Z. M.}

\section{INTRODACTION}

Objective social processes not only transform the worldview of man but also lead to the formation of a new image of modern reality. In recent decades, more changes have taken place in the scientific, technical, informational and social fields than in many previous centuries. A few centuries ago the nations lived apart and their ties were not significant. The processes that took place in the XIX and $\mathrm{XX}$ centuries led to dramatic changes. Engineering, economics, land and sea transport have significantly increased human mobility and transformation capabilities. The interdependence of the processes of the world economy and culture has also increased. The emergence and rapid development of the aviation and space industries in the early twentieth century greatly accelerated this process. As a result, there are no places unknown to people on earth, virtually no clean territories of water or air space, the condition of which would remain outside the influence of human transformation activity. All this gives grounds to call our planet now a "common home", "an island in the universe", "a boat in the stormy ocean", "world village", etc. Therefore, problems that have become common to all have become global.

Since the 90s of the XX century, the phenomenon of globalization has become known to many, despite the fact that its first signs began to appear in the 50s. It is well known that after the end of the Second World War a new world order was formed. Two ideological camps emerged: the Communist, together with its military bloc (the Warsaw Pact countries), and the capitalist one, which formed the North Atlantic Alliance. The other countries, the so-called "Third World", were an arena where two warring camps competed, but they themselves did not play a significant role in world political processes. In other words, they were the object, not the subject of world politics.

Globalization is a comprehensive multifaceted process of transforming the world into a coherent system that defines the future 
of human civilization. Globalization is the most important, influential and expressive process in today's global social relations. In a generalized definition, globalization is interpreted as a new stage of world development, qualitatively different from previous historical formations, and characterized by a sharp acceleration of the rate of internationalization of all spheres of public life - economic, social, political, spiritual - and bringing them to a new qualitative level. An unprecedented acceleration of the pace of social change in the modern era was analyzed by A. Toffler. The social collision between the present and the future has been described as a "Future Shock" .

Predicting the direction of modern globalization is becoming one of the most pressing problems of the global community. Due to the fact that it is difficult to predict what impact these processes can have on the current situation, when the sociocultural and spiritual crisis of man is growing against the background of the ecological crisis. It is also worth noting the widespread use of nuclear energy, the new advances in genetic engineering and the expansion of information technologies that cause the emergence of life-threatening, yet uncontrollable and unpredictable consequences. Not only economics, politics, culture, but also human consciousness are included in the processes of globalization: the ideas of the person about the world, society are transformed, the mechanisms of choice of life strategies change. The person faces the problem of internal self-determination; formation of priorities and a new value system.

Freedom is one of the main philosophical categories that characterize the essence of man and his existence, which manifests in the ability of the individual to think and act following their ideas and desires, and not due to internal or external coercion. For the individual, the possession of freedom is a historical, social and moral imperative, a criterion for his individuality and the level of development of society. Restrictions on the freedom of the individual, rigid regulation of his consciousness and behavior, reduction of the person to the role of a simple "screw" in social and technological systems are detrimental to both the individual and society. Ultimately, it is through personal freedom that society becomes able not only to adapt to existing natural and social circumstances of the surrounding

${ }^{1}$ Тоффлер А. Столкновение с будущим. Москва, 1972. С. 8. 
reality, but also to transform them under their goals. In this case, individual freedom can be the key to predicting globalization in different regions of the world.

\section{The phenomenon of globalization in the modern world and the freedom of the individual}

After the destruction of the bipolar world model, the world gradually became more homogeneous, and the difference between cultures began to be thought of as the main contradiction of the present. Current processes are the subject of much intellectual thinking.

Globalization can be called the process of total integration. In this case, it is fundamentally different from all forms of integration that existed in world history before. Humanity was still familiar with two forms of integration:

1. When any strong state is forcibly trying to "annex" other countries, and this form of integration we can call integration through absorption, using coercion (thus almost all empires were created).

2. A voluntary Association of countries to achieve a common goal. We can call this form of integration voluntary Union Confederation.

In both cases, the territories in which integration took place were relatively small and did not reach the scale typical of the current globalization process ${ }^{2}$.

Globalization aims to transform some sphere of life - economic, political, spiritual or social. It is a change of the whole paradigm of human life as a whole and every individual. On the one hand, globalization processes contribute to stabilizing the economic situation, channeling integrative tendencies in the political sphere, but on the other hand, the logical end of globalization can be the removal of not only economic and political barriers, but also cultural and ethnic unification.

In a globalizing world, personality development is a complex and contradictory process: on the one hand, the limits of external freedom are expanding on the basis of the development of new types of

${ }^{2}$ Иваненко М.И. Практика глобализации: игры и правила новой эпохи. Москва, 2005. 161 с. С. 81. 
communication, various communication infrastructures, social and political institutions, on the other, there is a process of strengthening the alienation of the individual from society, states, from other personalities and our nature. The primitive forms of spiritual selfrealization of man are brought to the fore. Today, instead of several available local TV and radio programs, you can choose from hundreds of programs offered by different countries and companies; almost any book can be found and read online; you can start a personal website or blog on the Internet and your thoughts will be potentially available worldwide; it is possible to choose religion (or atheism) not according to the traditions of your place of birth, but according to your wishes or needs, you can move relatively freely around the world, buy any goods, live and work in different countries. The latter (external, physical freedom, freedom of movement) is often one of the fundamental values in the modern world.

In terms of the American thinker Fukuyama, with the onset of the post-communist era, there is an end to history. Fukuyama believes that world history has moved to a whole new level, at which the contradictions and the driving force of history are removed, and the modern world is emerging as a single society. Leveling national societies and becoming a unified world community will mark the end of history: there will be no major change after that. History is no longer a field of conflict between individual nations or states, cultures and ideologies. It will be replaced by the universal and homogeneous state of mankind ${ }^{3}$.

Another view is expressed by the American thinker Huntington. In his opinion, at the present stage, the place of ideological contradictions is occupied by the contradictions of cultures (civilizations). The process of political homogenization of the world will cause civilizational conflicts ${ }^{4}$.

For a long time, the phenomenon of globalization was considered in sociopolitical theories mainly from the standpoint of economiccentrism. V. Lenin and M. Bukharin, as representatives of the theory of imperialism, noted the tendency of society to globalization, but in

${ }^{3}$ Молохович Р.А. Авторы и противники глобализации. Москва, 2006. 394 с. C. 33 .

${ }^{4}$ Молохович Р.А. Авторы и противники глобализации. Москва, 2006. 394 с. C. 35 . 
terms of economic expansion of imperialism - the conquest, colonization and economic control. The authors understood imperialism as the pinnacle of the development of capitalism. Economic expansion solves three major problems: the acquisition of cheap labor, cheap raw materials, and broad commodity markets. As a result, there is an asymmetry in the world economy: metropolises are exploited by less developed societies. Only the worldwide reformation of the proletariat can solve this problem in the context of this theory.

In 50-60 years of the XX century in Latin America, the theory of dependence was created. It considers the idea that underdeveloped countries are lagging behind not only internal problems but also external ones. Continuing to develop the idea of the author of the theory of dependence, P. Prebish, F. Cardozo, and E. Falleto explained the dependent development of the lack of independent high technologies and the developed national production of basic goods. Researchers have condemned the ugly forms of dependent capitalism: in their view, the accumulation, expansion, and self-realization of local capital require constant outside support. So, to survive, dependent capitalism must join the system of world capitalism.

I. Wallerstein is one of the creators of the concept of world economic dependence. Wallerstein emphasized that a market capitalist system has the potential for expansion. According to Wallerstein, the world system has three levels of states: central, peripheral and semiperipheral. The underdeveloped peripheral states are influenced by the leaders. The asymmetry and hierarchy of the world system will continue in the future, beyond the general processes of accelerating world development. Wallerstein viewed the world system as a systemglobal phenomenon, in which the supranational global factors play a major role.

The theory of world-systems by I. Wallerstein was created based on the neo-Marxist approach of AG Frank ${ }^{5}$ and the theory of the "Annals" school, the doctrine of the "world of economy" by F. Brodel ${ }^{6}$ world systems and sustainable social integrity. Not only do world systems unite different parts of civilizations, they also play a

${ }^{5}$ Frank A G I L Beds. The World - system; Five handred years or Five Thousand / London: Rouflege, 1993.

6 Бродель Ф. Материальная цивилизация, экономика и капитализм XV XVIII в. Т. 3. Время мира. Москва, 1992. 679 с. 
systematic role in their formation. The main types of world-systems are mini-systems, world empires, and world economies.

Mini systems are world systems with primitive means of production. The world empires have formed the basis of world economies, world systems with the logic of unequal exchange. On this basis, a modern world economy was created with a single world market, many politically independent states, a center, and a leader ${ }^{7}$.

According to Wallerstein, the main means of production were named mini-systems, world empires, and world economies. At the heart of Wallerstein's analysis is the world capitalist economy. Its main driving force is the accumulation of capital on a global scale. The modern world capitalist economy has a structure consisting of three tiers - the nucleus, the periphery, and the periphery. The stability of the world economy depends on its three components. The semiperiphery plays the same role as the center in the political systems of most countries. In the middle are the societies that are leaders of progress, the initiators of modernization, who have been able to organize it organically. Outsourcing countries include outsiders of world progress, which are exploitable by the leading countries. The hemisphere is the third structural component of the world economy. Semi-peripheral societies are unable to modernize organically. They have to go by borrowing someone else's models. In these states, the interference with another's ideology of European rationalism is seen as a violation of traditional values. As a result, such societies reconcile the rational with the irrational, the modern with the traditional, and the new with the patriarchal. This inorganic reconciliation is the main source of internal contradictions, "late societies".

Discoveries of global problems, as well as discoveries in the exact sciences, bring us back, according to OS Panarin, to ancient cosmocentrism. In the cosmocentric model of the world, the great doctrines of the modern era (communism, liberalism, etc.), which guarantee a predetermined future, testify to their failure. The second procedure for the creation of the future as another is the "rehabilitation of space", which has remained unaddressed in the formationprogressive picture of the world. Today, according to OS Panarin, the spatial dimension becomes a procedure for discovering such factors

7 Розов Н. С. Структура социальной онтологии: по пути к синтезу макроисторических парадигм. Bопросы философии. Москва, 1999. № 2. С. 12. 
that do not fit into information schemes, the concept of "formation of civilizations", the ethnic cultural barrier, the North-South dichotomy, etc. Culture is another source of unprogrammed others, according to Panarin. Culture by its nature is unambiguous. Finally, another source of another is politics. "In the twentieth century," Panarin writes, "those who were engaged in the reproduction of society were always victorious, and those who believed in its natural development and refrained from being active," when the decisive moment came. In general, therefore, the future acts as a product of politics. OS Panarin defines politics as the production of an unpredictable future.. ${ }^{8}$. He emphasized that the policy is not a planned but spontaneous production.

Another globalist theoretical system, an alternative theory of world systems, is the concept of Cheshkov. If Panarin's theory corrects the dynamic aspect of world system concepts, then Cheshkov's concept ${ }^{9}$ is spatial. The main idea behind its concept is a holistic approach to the study of the development of the world community. It was created based on the simultaneous use of such filters of benefits as "school of dependence", "oriental studies", "ecology".

Globalization is neither an association by military force (through military force can be used as an aid) nor a voluntary association. Its essence is fundamentally different: it is based on the idea of mutual benefit and material well-being. The transformation of nation-state corporations into transnationals, first and foremost, requires the same political and legal space to ensure the security of capital. Globalization can be seen as the logical result of a new European liberal project, which underlies the scientist paradigm of the European culture of modern times, most prominently manifested itself at the end of the XX century. The desire for the development of science and education, as well as the international nature of science and technology have helped the emergence of new technologies, which, in turn, made it possible to "reduce" the world. It is no coincidence that

8 Панарин А. С. Глобальное политическое прогнозирование в условиях стратегической нестабильности. Москва, 1999.

9 Чешков М. А. Развивающийся мир и посттоталитарная Россия: новые конфигурации мирового пространства. В поисках глобального и теоретического синтеза. Москва, 1994. 174 с. 
for the armed society of modern technology, the earth is already small, and efforts are directed to space exploration ${ }^{10}$.

At this stage, the idea of the consequences of the processes that started with globalization, most often, in General, is different: it focuses on technological and economic aspects of world development, there is no clear understanding of what the world has entered a period of instability and new shocks that will be called by the joint action of various factors - from environmental to cultural-civilizational. "... the diagnosis of the global risk society: global ... make a shaky support structure the traditional security calculations; the harmful consequences of losing spatial and time boundaries, find sustainable global in scope; responsibility for the damage cannot be put on certain instance - the principle of causality loses its sharpness of discernment, the losses cannot be compensated from financial sources, it is pointless to seek salvation from the consequences of a worst-case scenario of a global spiral of destruction. Therefore, there is no survival plan, if such worst-case will become reality"11.

The main characteristic of the globalization process taking place in the modern world is the extrapolation of liberal democratic values to all regions without exception. This means that the political, economic, legal and other systems of all countries of the world are becoming identical, and the interdependence of the countries reaches unprecedented proportions. Until now, peoples and cultures have never been so dependent on each other. Problems that occur anywhere in the world are instantly reflected throughout the rest of the world. The process of globalization and homogenization leads to the creation of a single world community, in which uniform norms, institutions, and cultural values are formed. There is a sense of peace as one place.

The problem of freedom in philosophy is usually understood in relation to man and his behavior (freedom in nature was conceived as an accident, as an "unknowable necessity"). In the history of philosophy, freedom has traditionally been considered in its relation to necessity. It has developed in such philosophical problems as freedom of will and responsibility of a person, the opportunity to be free, freedom as a force, regulating public relations.

10 Булавский Л.В. Проблема современности в контексте модернизации и глобализации. 2005. Вып. № 6. 115 с. С. 60.

${ }^{11}$ Бек У. Что такое глобализация? - Москва, 2001. С. 79-80. 
For a person, the possession of freedom is a historical, social and moral imperative (command), the criterion of his individuality and the level of development of society. The arbitrary restriction of a person's freedom, the rigid regulation of his consciousness and behavior, the reduction of a person to a mere "tool" in social and technological systems, harms both the individual and society. In the end, it is through the freedom of the individual that society becomes able not only to adapt to the existing natural and social circumstances of the surrounding reality, but also to transform them according to their goals. The specific material carrier of freedom, its subject, is always a person, and accordingly those communities in which it is included nations, social groups, classes.

Specialists who work today on the problem of individual freedom, as the theoretical basis of philosophical understanding of individual freedom is usually referred to concepts related to existentialist (or sub Kittim) trends in philosophical science, in which society is defined not as an objective structure, but as a result of the large number of people that have the freedom of choice. However, some conceptual provisions formulated in the framework of $\mathrm{Ob}$ actives direction, in particular in the sociological legacy of E. Durkheim, have a certain heuristic potential of the interpretation of the phenomenon of freedom. As you know, E. Durkheim focuses not on the individual in society and society in man. The individual is the organism that is even in the process of individualization implements social values and norms, which allows him to become an element of social structure. Social facts constrain individual actions that are no less rigidly than natural. He believed that people do not always passively perceive social norms, traditions, customs, etc., which are imposed on it from without, by society ${ }^{12}$.

Durkheim believed that the interaction between personality and society was significantly different in different types of societies. According to him, in an industrial society, which is a much more differentiated system compared to the traditional one, communication between the individual and society is mediated through the industrialization of human consciousness and behavior, its personal qualities. However, the manifestation of individual-personal properties

${ }^{12}$ Дюркгейм Э. О разделении общественного труда. Одесса, 1900. - 432 с. 
does not weaken but strengthens the position of the person in the system of social division of labor. In industrial society, according to Durkheim, there is an increase in the saturation of social interaction, which leads to the differentiation of social roles. In turn, this causes the transformation of the normative-value system on which the individual relies on his life. Durkheim argued with Tonnis, who believed that industrial society had lost its spirit of community, so that it could only be restrained by external coercive force. According to Durkheim, the development of personal qualities makes a person of industrial society relatively self-sufficient, freer. Thus, E. Durkheim holds a significant place in the theoretical and methodological arsenal of studies of freedom ${ }^{13}$.

As noted, subjectivize philosophy recognizes a degree of individual freedom from society and its institutions. Among its representatives is $\mathrm{M}$. Weber. the main task of "understanding sociology" he considered an understanding of social action to explain the process of this action ${ }^{14}$. Within this approach, the driving forces of social transformation are seen in individual subjectivity, which can only be actualized under the conditions of personal freedom of action.

An increase in the degree of freedom of a person can rule according to the criterion of social progress. At different stages of human history, the possibility of free choice of personality was unequal. As society develops, with each new era new opportunities for increasing the degree of individual freedom are opened. This position in modern social science, both in the West and in the East has become widely recognized. Every social formation or civilization is progressive insofar as they extend the circle of rights and freedoms of a person; create the conditions for his self-realization. However, it should not be forgotten that freedom can only be a criterion for social progress when its growth occurs within reasonable limits. When these boundaries at any stage of society's development are the responsibility of the individual to society and go beyond these boundaries, anarchy inevitably begins in society, which is not compatible with the concept of "freedom".

In General, the process of globalization is characterized by the following key aspects: internationalization, which primarily finds its

\footnotetext{
13 Дюркгейм Э. О разделении общественного труда. Одесса, 1900. - 432 с.

${ }^{14}$ Вебер М. Избранные произведения / М. Вебер. Москва, 1990. 808 с.
} 
expression in interdependence; liberalization, i.e. the removal of trade barriers, mobility of investment and development of integration processes; extrapolation of liberal values and modern technology all over the world; and, finally, deterritorialization, resulting in activity that has transnational scope, and the reduction of the salience of state borders. A comprehensive process of globalization at the detailed analysis covers mainly the following areas: information globalization, economic globalization, territorial globalization (regionalization), and demographic globalization. Also, today the main criterion of social progress is the level of humanization of society, the position in it of the individual - level economic, political, social and spiritual freedom.

\section{Socio-philosophical aspect of the impact of globalization on individual freedom}

No country and culture, no region in the world don't shy away from globalization. But, although this process is irreversible, it has overt and covert opponents. However, it is interested in globalization, a country not afraid to use force, examples of which are the events in Yugoslavia, Afghanistan, and Iraq.

In the process of globalization the participation of all economically, financially and politically advanced countries, as the main patron of this process is still perceived by the United States of America. After the Second World War, the United States actively involved in global political processes. Conducting integrated with Western European countries' policies; America is becoming one of the main factors constraining the spread of communism. Since the 60 -is of the last century, the United States has gradually become a world political leader. The implementation of the new European liberal-democratic project has been implemented in this country, which led to its military and economic success.

Many of the effects of globalization are linked to the economy. Building on the achievements of the NTP, the economy seeks to transform itself from an instrument of social life into the philosophy and ideology of a globalizing world. Through the economy, NTP influences civilizational progress.

The fashionable term "globalization" is found on the pages of almost all research on contemporary problems of higher education. When considering education issues in the context of globalization, we 
are talking about the impact of globalization on the development of higher education and the role of higher education in this process.

British researcher P. Scott notes that universities are also involved in the process of globalization ${ }^{15}$. Globalization, according to many Western experts, is the most fundamental challenge faced by the University for all time of its existence. The main factor that influenced the universities, in their opinion, is the economic ideology of globalization $^{16}$. Globalization is a new stage of human development in the study to avoid a linear progressives approach. Starting in the economic sphere, globalization processes have led to social transformations and their impact on the inner world of man. Analyzing globalization in the context of modern civilization processes S. Would. Crimean notes: "Thus, the civilization process in the world-wide scale is not reducible to globalization. It will not eliminate ethnic system planets and the fundamental differentiation of cultures with their value characteristics and archetypes. Mankind was and is an ethnic archipelago. This creates opposition to the background of globalization, moreover, causes the reverse wave regarding radicalization programs of planetary unification of humanity"17.

Globalization is becoming a dominant trend in modern world development and, at the same time, it is a spontaneous, largely uncontrollable character. A new problem with contemporary reality is whether it is possible to detect the degree of probability of predicting the direction of globalization processes and then managing them. Is it possible to regulate them in principle? Because it is quite possible that the processes of globalization, which are formed spontaneously, will not be managed by either man or society. By managing the processes of globalization, we mean combining them with processes of political, cultural, social and economic development that are relevant both to individual countries and to the entire world community.

15 Косиченко А.Г. Национальные культуры в процессе глобализации. Электронный информационно-аналитический бюллетень. 2000, Москва. № 8, 9. C. 15. 394 c.

16 Молохович Р.А. Авторы и противники глобализации. Москва, 2006.

17 Крымский С.Б. Цивилизационный статус глобализации. Практична філософія. Київ, 2001. № 2. С. 133-138. 
Globalization processes face different forms of resistance. Resistance to globalization can manifest itself in a wide variety of industries. Some of them have political, some - economic, and many cultural content. Let's briefly describe each of the forms. Political resistance, first of all, is manifested against the background of the decomposition of nation-states and the diminishing role of international institutions. The transformation of the essence of international politics is caused by the emergence of such global problems as the problem of human rights, the problem of ecology and weapons of mass destruction. For these reasons, the function and significance of traditional nation-states are diminished. They are no longer capable of pursuing independent policies. Fear of globalization gives rise to internal separatism as a form of resistance to this "danger". Aphasia in Georgia, Basque Country in Spain, Ulster in England, Quebec in Canada, Chechnya in Russia and many others are illustrations of the latter phenomenon ${ }^{18}$.

The role and importance of the state in the age of globalization is diminishing also in the aspect of devaluation of military security. In addition, economic and environmental security requires the simultaneous and concerted actions of many countries. Global markets have put many countries on their knees. Transnational corporations have greater financial capacity than national states. Awareness of all this contributes to a decrease in attachment to nation-states and, consequently, an increase in cosmopolitanism. One should not ignore the fact that technological and especially cultural monotony undermines the foundations of the nation-state.

The English international affairs researcher Strange identifies three paradoxes associated with the state in a time of globalization: increasing the role of government in the Scandinavian countries, the desire of these countries for isolation and neutrality, the emergence of the so-called. "Asian Tigers", that is, countries that under the conditions of illiberal rule carried out "economic miracle"19.

18 Орлов Ф.И. Социальные издержки глобализации. Социологические исследования. Москва, 2006. № 5. С. 59.

19 Косиченко А.Г. Национальные культуры в процессе глобализации. Электронный информационно-аналитический бюллетень. 2000, Москва. № 8, 9. C. 15. 
The economic arguments of the opponents of globalization are as follows. They believe that in this process, national governments are losing control over their economies, and rich countries do not provide guarantees of social protection. Consequently, inequality is deepening, both in a specific country and between different countries. Antiglobalists believe that their bourgeoisie sold out to foreign capital, and its concern for their enrichment will lead to even greater impoverishment of the population. In other words, the anti-globalists believe that globalization will lead to the further enrichment of the rich and, consequently, to the impoverishment of the poor ${ }^{20}$. The cultural opposition of globalization processes is much more serious and therefore requires special attention. What are you afraid of the country-opponents of globalization? After all, globalization, in its ideal embodiment, is the eradication of poverty; establish world order, eternal peace, and material prosperity. What is the force that makes a person, peoples, and countries to abandon the above benefits? What are the motives of this conflict?

As a positive moment in a globalized society, it is possible to allocate the development of new types of communication infrastructure, particularly Internet resources, which can significantly enhance human creativity, making it a heuristic horizon. However, one cannot deny the negative aspects of globalization transformations, which leave their imprint on the development of the individual and related primarily to the dissemination and strengthening of positions of mass culture.

The fact that the representatives of the original cultures, consciously or subconsciously, feel that the economic, political, legal, and technological homogenization will inevitably take place side effects that, primarily, will cause a change in their traditions, national culture and the whole lifestyle. One of the essential human needs affiliation to something, be it a social group, denomination, political orientation, geographical area, etc. Among these forms of identity cultural identity is the main and comprehensive, because it largely determines the mentality, the psychology and way of life in General. Need to be an apologist of the "conspiracy theory" to accuse the USA that they developed this ideology that intends to destroy the diversity

20 Электронный портал URL: www.earthecharter.org. 
of cultures and languages, to make the world culturally homogeneous ${ }^{21}$.

For the national consciousness, a nation's way of life is perceived not only as a peculiar way of life, but also as an advantage over other cultures. For the national consciousness, the solidity of culture and way of life is conceived as overcoming the finite of being. Each representative of the nation sees the overcoming of their empirical limb in the immortality of national culture, where future generations will preserve the way of life inherent in that culture, as contemporaries do and as their ancestors did. The peculiar feeling that constantly accompanies national consciousness is the awareness of the identity of one's nation and its differences from other nations (the so-called national feeling that defines local color). Representatives of one nation are different from representatives of the other physical type, different also customs, type of behavior and household skills. In the course of historical development, the nation produces certain ideas and values.

Communicating with another culture often only increases sympathy for one's own nation. Awareness of belonging to a nation means that a person is connected to it by a community of character, that the fate and culture of the nation influence it, and that the nation itself lives and is realized in it. It perceives the nation as part of its "I"; therefore, the image of one's own nation is taken as a personal insult, and the success of one's own nation and recognition of others by others causes a sense of national pride. Man is so defined by culture that change, even in a field such as cooking, cuisine, table, is perceived as very painful.

One way or another, but globalization inevitably destroys national cultures. First of all, it refers to the national language, to its diminution. Successful economic activity requires timely information sharing in one language, and such a language in the context of globalization is undoubtedly English today. The particular individual, society, ethnic group is primarily self-identified with language as a pillar of national culture; so neglecting it, even reducing the range of its distribution, is perceived as painful. From a value point of view, language is not only a means of communication, that is, a medium of communication, but also the outlook and outlook of the native

21 Бирюкова М.А. Глобализация: интеграция и дифференциация культур. Философские науки. Москва, 2000. № 4. - С. 22. 
language of the language, it records the biography of the nation, it was spoken by ancestors and it is a model of the entire local world. Language is an integral feature of a nation: there is no nationality without language. In the national consciousness, language is perceived as a living organism that requires careful attitude and care. The loss of language is followed by the destruction of historical inheritance, the connection of times, memory ... Language is the object of love, and it is the axis of national culture, the object of respect, the basis of national consciousness. Therefore, the national language is a major cultural phenomenon. There is no culture without language. This means that language is not only crucial to any particular, individually existing cultural environment but if something exists in the culture; it has its design in the language. In other words, culture exists in language, and language is the most important way of expressing culture $^{22}$.

Opponents of globalization also feel that globalization processes cause a memory gap. National culture is a form of historical memory; it is a collective memory in which the fixation, preservation, and translation of the way of life, social and spiritual experience of a given society takes place. Culture as a memory preserves not everything that was created by the people, the bearer of that culture, but that which was objectively valuable to it. If we use an analogy and think about the meaning and role of memory in the real life of a particular person, then the significance of cultural memory in the life of a nation will become clearer. The person, losing memory, also loses his biography, his own "I" and his integrity; it exists physically but has no past, present, and future. She doesn't know who she is, what she exists for, what she wants, and the only way out is to start from scratch. The role played by memory in the life of the individual in the historical life of society and nation is played by national culture. Culture is a form of memory that is transmitted through generations, through which the cultural life of a nation preserves continuity, consistency, and unity. In biological organisms, this function is performed by gene structures. The social experience of people is passed on to the next generations not by blood, but through culture, and in this sense culture can be

22 Василенко И.А. Диалог цивилизаций. Москва, 1999. 290 с. С. 139. 
called a non-genetic memory ${ }^{23}$ of the diversity and contradiction of the impact of globalization and its consequences on personality and individual freedom, which is both in the emergence of positive tendencies, Allowing the person to more fully realize itself, and in the strengthening of negative tendencies increasingly entrenches and impoverishes the personality. The contradiction of the impact of globalization, its effects on the individual and his freedom is both the emergence of positive tendencies that allow the individual to more fully realize himself and in the negative tendencies increasingly enslaves and impoverishes the individual. Evidence of the ambiguity of the impact of globalization is the extension of the limits of external human freedom, on the one hand, and the increasing alienation of the individual from his nature, from other personalities, from society and the state, on the other. Highlighting the positive aspects of globalization, we can talk about the development of new types of communication, various social and political institutions, contributing to the expansion of information and mobility.

Social freedom is peculiar only to individuals living in society. Even in Kant's writings, the dualistic breeding of natural and free causality is traced. However, in contrasting the freedom of nature, Kant proposes to seek the kingdom of freedom not in nature but the world of man (in the world of social). But because he also understands a person dualistically (this being, on the one hand, is natural, sensually-empirical, and on the other - incomprehensibly, free and intelligent, besides unknowable), so Kant pushes aside the indefinite as historical perspective. The philosopher believes that freedom and necessity exist in different ways, they never and never intersect. These are two different perspectives on a person, two different personalities; therefore, there is no contradiction between freedom and the need for the same actions of a person. The division into "two natures" is also characteristic of Marx's teaching. Thus, "first nature" covers the geoand biosphere, that is, those material systems that have arisen and exist outside and independently of man, but at the same time may at the same time become objects of his activity. "Second nature" covers

23 Дзялошинский И. Культура, журналистика, толерантность. Материалы научно-практической конференции «Пресса, государство, культура: мультикультурализм как новая философия взаимодействия». Москва, 2002. 136 c. C. 72. 
not only non-living objects created by man and not existing in nature but also living organisms: plants, animals that are derived or created by man through artificial selection or genetic engineering. However, the artificial habitat does not come down to this material basis. A person can live and act only in the system of certain social relations. These social relations are carried out in certain material a condition, including artificially created by man, and together with the latter creates an artificial environment of human existence, the sphere of society.

The question of human freedom in the philosophical subject field can be regarded as the problem of desire itself or freedom of will, the problem of freedom of choice and the problem of freedom of action. Moreover, the emphasis is on the study of the problem of free will, that is, the study of the last grounds of our actions and motives.

In problem of free will addresses such questions as: is there freedom of desire that is a choice? As a rule, the responses of philosophers (regardless of their orientation to materialistic, psychic, theological, or some other "pure model" of determinism and indeterminism) are based on metaphysical statements and constructions.

Question of freedom of choice is complex. The central question here is the question of the intrinsic limits of desire itself: is human freedom able to choose between motives, or is it (freedom) merely the registrar that drives the strongest motive? Determinists believe that a person's freedom of life is reduced to a struggle of motives, in which the strongest motive automatically wins. Indeterminists - that human freedom is itself able to choose between different motives.

The problem with freedom of action is that a person can do what he wants if his own body does not interfere with it. As an external and internal prerequisite for any serious life activity, this freedom has long been considered a fundamental human right. However, it does not exhaust the problem of human freedom in the context of philosophy.

According to many modern researchers, freedom can be defined as the phenomenon of mentality of the person. It is the most universal and correct. This definition takes into account both the static and procedural characteristics of freedom. Worldview is a holistic image of reality; it must, first of all, appreciate nature. On the one hand, it is formed through processes such as assimilation and socialization, 
under the influence of a particular set of ideological perceptions, attitudes, beliefs, and stereotypes of consciousness, thinking, relationships, behavior, communication, activities and the like. On the other - is formed, the Outlook appears an essential prerequisite and an important factor in aging the subject of certain components of a worldview and to a large extent all his worldview in General, as a system covering the reality.

Thus, we can say that as a result of worldview, sensory and rational images are formed, which largely determine the process of development by the social subject of reality, its transition to the conscious level of cognition. Social perception is a form of development of social reality, which affects the regulation of the subject's behavior.

Concerning freedom, it should be noted that every time appears as a new "idea". Born at one time or another, a person holistically perceives this "idea" through the processes of development and socialization, which in turn are components of the worldview. In mastering this image, one distinguishes from the complex, multidimensional definition of freedom those components that are more relevant to him by individual and social factors. As a result, a person's perception of freedom can be divided into specific levels, namely: personal, interpersonal, institutional, political, which allows us to consider the features of this process.

\section{CONCLUSIONS}

In our opinion, the processes of globalization have led to the following results:

- the imbalance of economic development of different regions;

- commercialization of all spheres of life;

- globalization of the labor market;

- the deterioration of the ecological situation on the planet;

- increased gap between rich and poor (people and countries);

- lack of control over the activities of international financial institutions about the management of States whose citizens are included in the structure;

- the social stratification that was the cause of the growing tension, not only between representatives of different social groups in one country but also between countries. 
- the degradation of culture and decline in the spiritual life of society;

- globalization is manifested in the gap between economic and cultural patterns of development of different social systems;

- globalization is destroying national cultures. In particular, this applies to the national language, to the diminution of its value.

- subjective freedom with objective lack of freedom;

- the external, physical freedom, freedom of movement was a sign of globalization.

Important for the development of personality is the presence. Self-identification mechanisms based on deep individual and civilizational values. Personality grows and develops in a certain social, cultural and national environment, and the invasion of its development of alien cultural, social and other elements can lead to various irreversible processes.

So, today, globalization transformations challenge people and society, making them doubt their own identity. They urge either to stand by the proposed rules the right to occupy a worthy position in the new world system, or to create their variant of development, in which globalization is opposed by regionalization, centrifugal world order - polycentric, cultural unification - interest in national cultures, secularized traditional and religious values identity is a commitment to one's people.

\section{SUMMARY}

The article deals with the phenomenon of globalization in the modern world and the freedom of the individual. Globalization is a comprehensive multifaceted process of transforming the world into a coherent system that defines the future of human civilization. Globalization is the most important, influential and expressive process in today's global social relations. In a generalized definition, globalization is interpreted as a new stage of world development, qualitatively different from previous historical formations, and characterized by a sharp acceleration of the rate of internationalization of all spheres of public life - economic, social, political, spiritual and bringing them to a new qualitative level. The contradiction of the impact of globalization, its effects on the individual and his freedom is both the emergence of positive tendencies that allow the individual to 
more fully realize himself and in the negative tendencies increasingly enslaves and impoverishes the individual. Evidence of the ambiguity of the impact of globalization is the extension of the limits of external human freedom, on the one hand, and the increased alienation of the individual from his nature, from other personalities, from society and the state, on the other.

\section{REFERENCES}

1. Frank A G I L Beds. The World - system; Five handred years or Five Thousand / London, 1993.

2. Бек У. Что такое глобализация? - Москва, 2001. С. 79-80.

3.Бирюкова M. А. Глобализация: интеграция и дифференциация культур. Философские науки. Москва, 2000. № 4. - С. 74 .

4. Бродель Ф. Материальная цивилизация, экономика и капитализм XV - XVIII в. Т. 3. Москва, 1992. - 679 с.

5.Булавский Л. В. Проблема современности в контексте модернизации и глобализации. 2005. Вып. № 6. 115 с. С. 60.

6. Василенко И. А. Диалог цивилизаций. Москва, 1999. 290 с.

7. Вебер М. Избранные произведения / М. Вебер. Москва, $1990.808 \mathrm{c}$.

8. Дзялошинский И. Культура, журналистика, толерантность. Mатериальг научно-практической конференции "Пресса, государство, культура: мультикультурализм как новая философия взаимодействия”. Москва, 2002. 136 с.

9. Дюркгейм Э. О разделении общественного труда. Одесса, 1900. - 432 с.

10.Электронный портал URL: www.earthecharter.org.

11.Иваненко М. И. Практика глобализации: игры и правила новой эпохи. - Москва, 2005. 161 с.

12. Крымский С. Б. Цивилизационный статус глобализации. Практична філософія. Київ, 2001. № 2. С. 133-138.

13. Косиченко А. Г. Национальные культуры в процессе глобализации. Электронный информационно-аналитический бюллетень. 2000, Москва. № 8, 9. С. 15.

14. Молохович Р. А. Авторы и противники глобализации. Москва, 2006. 394 с. 
15.Орлов Ф. И. Социальные издержки глобализации. Сочиологические исследования. Москва, 2006. № 5. С. 59.

16. Панарин А. С. Глобальное политическое прогнозирование в условиях стратегической нестабильности. Москва, 1999.

17.Розов Н. С. Структура социальной онтологии: по пути к синтезу макроисторических парадигм / Н. С. Розов // Вопросы философии. - 1999. - № 2. - С. 12.

18. Тоффлер О. Футурошок. - СПб., 1997.

19. Чешков М. А. Развивающийся мир и посттоталитарная Россия: новые конфигурации мирового пространства. В поисках глобального и теоретического синтеза. Москва, 1994. 174 с.

\section{Information about the author:} Atamaniuk Z. M., Candidate of Philosophy, Associate at the Department of Philosophy, Sociology and Management of Socio-Cultural Activity, State Institution «South Ukrainian National Pedagogical University named after K. D. Ushynsky» 26, Staroportofrankivska str., Odesa, 65020, Ukraine 